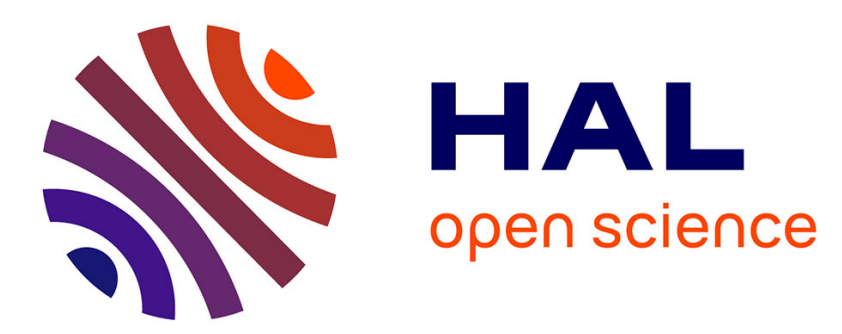

\title{
Review: Mechanistic target of rapamycin (mTOR) pathway, focal cortical dysplasia and epilepsy
}

\author{
E. Marsan, S. Baulac
}

\section{To cite this version:}

E. Marsan, S. Baulac. Review: Mechanistic target of rapamycin (mTOR) pathway, focal cortical dysplasia and epilepsy. Neuropathology and Applied Neurobiology, 2018, 44 (1), pp.6-17. 10.1111/nan.12463 . hal-02274845

\section{HAL Id: hal-02274845 \\ https://hal.sorbonne-universite.fr/hal-02274845}

Submitted on 30 Aug 2019

HAL is a multi-disciplinary open access archive for the deposit and dissemination of scientific research documents, whether they are published or not. The documents may come from teaching and research institutions in France or abroad, or from public or private research centers.
L'archive ouverte pluridisciplinaire HAL, est destinée au dépôt et à la diffusion de documents scientifiques de niveau recherche, publiés ou non, émanant des établissements d'enseignement et de recherche français ou étrangers, des laboratoires publics ou privés. 


\title{
Review: Mechanistic target of rapamycin (mTOR) pathway, focal cortical dysplasia and epilepsy
}

\author{
E. Marsan and S. Baulac \\ Department of Genetics and Cytogenetics, AP-HP, Institut du Cerveau et de la Moelle Epinière (ICM) - Hôpital Pitié- \\ Salpêtrière, Sorbonne Universités, UPMC Univ Paris 06 UMR S 1127, Inserm U1127, CNRS UMR 7225, Paris, \\ France
}

E. Marsan, S. Baulac (2018) Neuropathology and Applied Neurobiology 44, 6-17

Mechanistic target of rapamycin (mTOR) pathway, focal cortical dysplasia and epilepsy

Over the last decade, there has been increasing evidence that hyperactivation of the mechanistic target of rapamycin (mTOR) pathway is a hallmark of malformations of cortical development such as focal cortical dysplasia (FCD) or hemimegalencephaly. The mTOR pathway governs protein and lipid synthesis, cell growth and proliferation as well as metabolism and autophagy. The molecular genetic aetiology of
mTOR hyperactivation has only been recently clarified. This article will review the current and still evolving genetic advances in the elucidation of the molecular basis of FCD. Activating somatic mutations in the MTOR gene are to date the most frequent mutations found in FCD brain specimens.

Keywords: DEPDC5, focal cortical dysplasia, focal epilepsy, GATOR1, mTOR pathway, somatic mutations

\section{Introduction}

Focal cortical dysplasias (FCD) are localized malformations of cortical development (MCDs) that are commonly associated with drug-resistant epilepsy in both children and adults, often requiring resective surgery to control seizures. The International League Against Epilepsy (ILAE) diagnostic methods commission has proposed a classification system to categorize FCD entities based on their neuropathological features [1]: FCD I refers to isolated lesions, which present radial and/or tangential dyslamination of the cortex, FCD II is an isolated lesion characterized by cortical dyslamination and dysmorphic neurons without (FCD IIa) or with balloon cells (FCD IIb), and FCD III is associated to other brain lesions. The histopathological features of

Correspondence: Stéphanie Baulac, Institut du Cerveau et de la Moelle (ICM), Hôpital de la Pitié-Salpêtrière, 47 bd de l'hôpital, Paris F-75013, France. Tel: +331 5727 4339;

E-mail: stephanie.baulac@upmc.fr hemimegalencephaly (HME) resemble FCD II but the lesion extents to unilateral hemispheric enlargement. When the ILAE classification was reported in 2011, the genetic aetiology of FCD was unknown. FCD are often sporadic conditions (not inherited from an affected parent), and only a few subsets of studies reported a family history with multiple FCD individuals within the same family. So far, six families have been reported with the co-occurrence of FCD, ganglioglioma, HME and dysembryoplastic neuroepithelial tumours suggesting the existence of genetic determinants contributing to these related brain cortical lesions [2]. Two other pedigrees, with two first-degree relatives with an FCD in a context of familial focal epilepsy, were also reported [3]. Nevertheless, the majority of FCD are sporadic, and the molecular genetic aetiology of FCD has remained enigmatic until recent years.

Over the last decade, there has been increasing evidence that FCD II is linked to hyperactivation of the mechanistic target of rapamycin (mTOR) pathway. mTOR is a kinase ubiquitously expressed which is part 
of two complexes: mTOR complex 1 (mTORC1) when associated to the protein raptor or mTOR complex 2 (mTORC2) when bound to the protein Rictor. These two complexes regulate fundamental cell physiology processes in response to distinct cellular inputs including growth factors and nutrients. While mTORC2 mainly controls cell proliferation and survival, mTORC1 governs protein and lipid synthesis, cell growth and proliferation as well as metabolism and autophagy [4,5]. One commonly used readout of mTOR pathway activity is the phosphorylation by mTORC1 of its downstream S6 kinase (phospho-S6K, Thr389) and ribosomal protein S6 (phospho-S6, Ser235/6 or Ser240/4) substrates. In 2004, two studies linked FCD to mTORC1 hyperactivation [6,7]. These observations were subsequently confirmed by numerous studies demonstrating hyperphosphorylation of S6 in FCD IIa cytomegalic dysmorphic neurons and FCD IIb balloon cells [8]. Similar findings were reported in a variety of epilepsy-associated pathologies, and in multiple cell types including dysmorphic neurons, microglia and immature cells [9]. Constitutive activation of mTORC1 is also observed in tuberous sclerosis complex (TSC) and HME [10], indicating that dysregulation of the mTOR signalling pathway is a common hallmark to a spectrum of MCDs. Although an upregulation of the mTOR pathway has been associated to the pathogenesis of FCD II for more than a decade, the genetic events sustaining mTOR hyperactivation have only been recently clarified. This article will review the current and still evolving genetic advances in the elucidation of the molecular basis of FCD.

\section{Brain somatic mutations in the PI3K- PTEN-AKT3-TSC pathway}

\section{Phenotype and mutational spectrum}

Germline mutations in TSC1/2 (TSC), PTEN (phosphatase and tensin homolog) or AKT3 (AKT serine/ threonine kinase 3) and PIK3CA (phosphatidylinositol 3-kinase) are known to cause, respectively, TSC, Cowden or megalencephaly syndromes [11]. Brain somatic mutations occurring in a fraction of neurons during brain development have been suspected to underlie both the cellular mosaicism and the focal nature of FCD [12]. Remarkably, accumulating evidence supports the role of brain somatic mutations in TSC1/2, PTEN, AKT3 and PIK3CA genes in focal MCDs such as FCD type IIa and IIb or in HME (Table 1). Here we reviewed seven studies reporting 21 subjects with mosaic brain somatic mutations in genes belonging to the PI3KPTEN-AKT3-TSC1 pathway. In 2006, Schick et al. [13] detected a PTEN brain mosaic missense variant by Sanger sequencing of laser capture microdissected dysmorphic and balloon cells from a patient with FCD IIb. In 2012, Poduri et al. [14] reported brain somatic mutation and mosaic trisomy in AKT3 in 2/20 (10\%) patients with HME, and Lee et al. [15] described activating somatic mutations in PIK3CA and AKT3 in 5/ $20(25 \%)$ HME subjects. Conti et al. [16] identified a mosaic duplication in AKT3 in 1/16 (6\%) patients with focal or multilobar MCD. Jansen et al. [17] reported three activating variants in AKT3 and PIK3CA in 3/33 $(10 \%)$ of FCD II and HME cases. D'Gama et al. [18] detected activating mutations in PIK3CA in 4/53 (8\%) individuals with FCD or HME. Overall, pathogenic variants in AKT3 and PIK3CA account for $6-25 \%$ of these MCDs with allele frequency of mosaic mutations between $1.1 \%$ and $4.7 \%$ in FCD II and from $10 \%$ to $31 \%$ in HME (Table 1).

Recently, brain somatic missense variants were discovered using deep sequencing of targeted gene panels in TSC1 and TSC2 in 5/40 (12.5\%) FCD II individuals who were negative for MTOR mutations.

\section{Functional studies and animal models}

In vitro assays in heterologous mammalian cell lines (HEK293T) overexpressing TSC1 and TSC2 variants found in FCD subjects demonstrated S6K increased phosphorylation due to the disruption of the formation of the TSC1-TSC2 complex [19]. Increased S6 phosphorylation was also found in cytomegalic cells from brain specimens of patients with FCD IIa, FCD $\mathrm{IIb}$ or HME with mutations in PIK3CA, AKT3, TSC1 or TSC2 [14-16,19]. These data indicate mTORC1 hyperactivity observed in resected human brain tissue is likely due to mutations in genes of the pathway.

To model somatic mutations and brain focal malformations in vivo, multiple mouse models have been generated using in utero electroporation in embryonic mouse brains. A first study used a double-hit strategy to eliminate Tsc1 in discrete neuronal populations by in 
Table 1. Brain mosaic mutations in AKT3, PIK3CA, TSC1, TSC2 and PTEN reported in the literature

\begin{tabular}{|c|c|c|c|c|c|}
\hline \multirow[b]{2}{*}{ MCD type } & \multirow[b]{2}{*}{ Gene } & \multicolumn{2}{|l|}{ Mutation } & \multirow[b]{2}{*}{ Brain mosaic rate (\%) } & \multirow[b]{2}{*}{ References } \\
\hline & & DNA (nucleotide change) & Protein (amino acid change) & & \\
\hline $\begin{array}{l}\text { FCD Ib with subcortical } \\
\text { heterotopia }\end{array}$ & AKT3 & $\begin{array}{l}\text { Mosaic duplication } \\
\text { chr1q21.1-q44 }\end{array}$ & p.(?) & N/A & [16] \\
\hline FCD IIa & $\begin{array}{l}\text { TSC1 } \\
\text { TSC2 } \\
\text { TSC1 } \\
\text { TSC1 } \\
\text { PIK3CA }\end{array}$ & $\begin{array}{l}\text { c. } 610 \mathrm{C}>\mathrm{T} \\
\text { c. } 4639 \mathrm{G}>\mathrm{A} \\
\text { c. } 64 \mathrm{C}>\mathrm{T} \\
\text { c. } 64 \mathrm{C}>\mathrm{T} \\
\text { c. } 3140 \mathrm{~A}>\mathrm{G}\end{array}$ & $\begin{array}{l}\text { p.Arg204Cys } \\
\text { p.Val1547Ile } \\
\text { p.Arg22Trp } \\
\text { p.Arg22Trp } \\
\text { p.His1047Arg }\end{array}$ & $\begin{array}{l}1.1 \\
1.55 \\
1.98 \\
2.1 \\
4.7\end{array}$ & $\begin{array}{l}{[19]} \\
{[19]} \\
{[19]} \\
{[19]} \\
{[17]}\end{array}$ \\
\hline FCD IIb & $\begin{array}{l}\text { PTEN } \\
\text { TSC1 }\end{array}$ & $\begin{array}{l}\text { c. } 834 \mathrm{C}>\mathrm{G} \\
\text { c. } 64 \mathrm{C}>\mathrm{T}\end{array}$ & $\begin{array}{l}\text { p.Phe278Leu } \\
\text { p.Arg22Trp }\end{array}$ & $\begin{array}{l}\mathrm{N} / \mathrm{A} \\
1.37\end{array}$ & $\begin{array}{l}{[13]} \\
{[19]}\end{array}$ \\
\hline HME & $\begin{array}{l}\text { AKT3 } \\
\text { PIK3CA } \\
\text { AKT3 } \\
\text { PIK3CA } \\
\text { PIK3CA } \\
\text { PIK3CA } \\
\text { AKT3 } \\
\text { PIK3CA } \\
\text { PIK3CA } \\
\text { AKT3 } \\
\text { PIK3CA }\end{array}$ & $\begin{array}{l}\text { Mosaic trisomy chr1q } \\
\text { c. } 1633 \mathrm{G}>\mathrm{A} \\
\text { c. } 49 \mathrm{C}>\mathrm{T} \\
\text { c. } 3140 \mathrm{~A}>\mathrm{G} \\
\text { c. } 1624 \mathrm{G}>\mathrm{A} \\
\text { c. } 1633 \mathrm{G}>\mathrm{A} \\
\text { c. } 49 \mathrm{C}>\mathrm{T} \\
\text { c. } 1633 \mathrm{G}>\mathrm{A} \\
\text { c. } 1624 \mathrm{G}>\mathrm{A} \\
\text { c. } 49 \mathrm{C}>\mathrm{T} \\
\text { c. }[1624 \mathrm{G}>\mathrm{A} ; 1631 \mathrm{C}>\mathrm{A}]\end{array}$ & $\begin{array}{l}\text { p.(?) } \\
\text { p.Glu545Lys } \\
\text { p.Glu17Lys } \\
\text { p.His1047Arg } \\
\text { p.Glu542Lys } \\
\text { p.Glu545Lys } \\
\text { p.Glu17Lys } \\
\text { p.Glu545Lys } \\
\text { p.Glu542Lys } \\
\text { p.Glu17Lys } \\
\text { p.[Glu542Lys, Thr544Asn] }\end{array}$ & $\begin{array}{l}\text { N/A } \\
\text { N/A } \\
10-18 \\
13 \\
16 \\
17 \\
17.4 \\
18 \\
28 \\
28 \\
31\end{array}$ & $\begin{array}{l}{[14]} \\
3 \text { patients }[15] \\
{[17]} \\
{[18]} \\
{[15]} \\
{[18]} \\
{[14]} \\
{[18]} \\
{[18]} \\
{[15]} \\
{[17]}\end{array}$ \\
\hline
\end{tabular}

MCD, malformations of cortical development; FCD, focal cortical dysplasia; HME, hemimegalencephaly; chr, chromosome; N/A, not available.

utero electroporation of pCAG-Cre in E15-16 Tsc $1^{f / m u t}$ mouse embryos. Mice presented TSC syndrome-like cortical lesions as well as a lower seizure threshold compared to wild-type animals [20]. A second study achieved a knockdown of Tsc2 by in utero electroporation of shRNA targeting Tsc2 in E14 mouse embryos. The resulting phenotype consisted in a disorganization of the cortical lamination, the presence of mTORC1 hyperactivated cytomegalic cells, but apparently no spontaneous seizures [21]. Recently, Lim et al. achieved in utero CRISPR-Cas9-mediated genome editing of Tsc1 and Tsc2 in E14 mouse embryos. The mouse phenotype is reminiscent of FCD II with spontaneous seizures and cortical malformations, consisting of cortical dyslamination and mTORC1 hyperactivated cytomegalic neurons [19]. In addition, a mouse model in which the recurrent AKT3 p.Glu17Lys mutation was introduced at E14.5 using in utero electroporation resulted in unprovoked excessive electrical activity and impaired focal architecture consisting of neuronal heterotopias, noncell autonomous migration defect and mTORC1 hyperactivated dysmorphic neurons, reminiscent of FCD and HME. Brain malformations were prevented by rapamycin injection [22].
Moreover, numerous constitutive and conditional murine knockout (KO) models have been generated in the past to study the effect of loss-of-function of Tsc1 or Tsc2 as well as the effect of PIK3CA activating mutations. Among these models, the Tsc1 Synapsin1-cre conditional KO generated on a heterozygote background $\left(\right.$ Tsc $\left.^{\mathrm{c} /}{ }^{-} \mathrm{KO}\right)$ exhibits brain lesions and spontaneous seizures reminiscent of patients with TSC syndrome [23]. Another study achieved a brain-specific mosaic neuronal inactivation of Tsc1 in neuronal progenitor cells in $\mathrm{Tsc}^{\mathrm{c} / \mathrm{c}}$ Nestin-rtTA+ TetOp-cre+ mouse embryos at E13.5. The phenotype encompassed spontaneous epileptic seizures accompanied by premature death, as well as brain malformations consisting of enlarged dysmorphic neurons and astrocytes presenting increased mTORC1 activity, reminiscent of giant cells present in TSC tubers. Postnatal rapamycin treatment reversed these phenotypes [24]. Furthermore, a mouse model expressing the recurrent activating PIK3CA p.Glu545Lys variant in developing neural progenitors, under the control of the Nestin-cre promotor, led to megalencephaly, cortical and white matter dysplasia, as well as cytomegalic cells and epilepsy. This phenotype is reminiscent of malformations of the cortical development [25]. 
Table 2. Brain mosaic mutations in MTOR reported in the literature

\begin{tabular}{|c|c|c|c|c|}
\hline \multirow[b]{2}{*}{ MCD type } & \multicolumn{2}{|l|}{ Mutations } & \multirow[b]{2}{*}{ Brain mosaic rate (\%) } & \multirow[b]{2}{*}{ References } \\
\hline & $\begin{array}{l}\text { DNA } \\
\text { (nucleotide change) }\end{array}$ & $\begin{array}{l}\text { Protein } \\
\text { (amino acid change) }\end{array}$ & & \\
\hline \multirow[t]{12}{*}{ FCD IIa } & c. $6644 \mathrm{C}>\mathrm{T}$ & p.Ser2215Phe & 0.93 & {$[30]$} \\
\hline & c. $6644 \mathrm{C}>\mathrm{A}$ & p.Ser2215Tyr & 1.06 & {$[30]$} \\
\hline & c. $6644 \mathrm{C}>\mathrm{T}$ & p.Ser2215Phe & $1.2-8.6$ & {$[29]$} \\
\hline & c. $6577 \mathrm{C}>\mathrm{T}$ & p.Arg2193Cys & 1.26 & {$[26]$} \\
\hline & c. $5126 \mathrm{G}>\mathrm{A}$ & p.Arg $1709 \mathrm{His}$ & 1.52 & {$[26]$} \\
\hline & c. $7280 \mathrm{~T}>\mathrm{C}$ & p.Leu2427Pro & $3.48-7.28$ & {$[26]$} \\
\hline & c. $6644 \mathrm{C}>\mathrm{A}$ & p.Ser2215Tyr & 3.5 & [29] \\
\hline & c. $1871 \mathrm{G}>\mathrm{A}$ & p.Arg624His & 4.41 & {$[26]$} \\
\hline & c. $6644 \mathrm{C}>\mathrm{T}$ & p.Ser2215Phe & 5.5 & [29] \\
\hline & c. $4379 \mathrm{~T}>\mathrm{C}$ & p.Leu1460Pro & 6 & [29] \\
\hline & c. $7280 \mathrm{~T}>\mathrm{C}$ & p.Leu2427Pro & $6.57-12.63$ & {$[26]$} \\
\hline & c. $4487 \mathrm{~T}>\mathrm{G}$ & p.Trp1456Gly & 8 & {$[28]$} \\
\hline \multirow[t]{17}{*}{ FCD IIb } & c. $5930 \mathrm{C}>\mathrm{A}$ & p.Thr1977Lys & 1.51 & {$[26]$} \\
\hline & c. $6644 \mathrm{C}>\mathrm{A}$ & p.Ser2215Tyr & 1.54 & {$[27]$} \\
\hline & c. $4379 \mathrm{~T}>\mathrm{C}$ & p.Leu1460Pro & 1.59 & {$[27]$} \\
\hline & c. $4376 \mathrm{C}>\mathrm{A}$ & p.Ala1459Asp & 1.65 & {$[27]$} \\
\hline & c. $6644 \mathrm{C}>\mathrm{T}$ & p.Ser2215Phe & 2.11 & [26] \\
\hline & c. $6644 \mathrm{C}>\mathrm{T}$ & p.Ser2215Phe & 2.33 & {$[26]$} \\
\hline & c. $4375 \mathrm{G}>\mathrm{T}+$ c. $4379 \mathrm{~T}>\mathrm{C}$ & p.Ala1459Ser + p.Leu1460Pro & 2.41 and 2.46 & {$[30]$} \\
\hline & c. $6644 \mathrm{C}>\mathrm{T}$ & p.Ser2215Phe & 2.62 & [30] \\
\hline & c. $7280 \mathrm{~T}>\mathrm{A}$ & p.Leu2427Gln & $2.86-5.11$ & {$[26]$} \\
\hline & c. $5930 \mathrm{C}>\mathrm{A}$ & p.Thr1977Lys & 2.93 & {$[26]$} \\
\hline & c. $6644 \mathrm{C}>\mathrm{T}$ & p.Ser2215Phe & 3.11 & {$[27]$} \\
\hline & c. $6644 \mathrm{C}>\mathrm{A}$ & p.Ser2215Tyr & 3.67 & [30] \\
\hline & c. $4348 \mathrm{~T}>\mathrm{G}$ & p.Tyr1450Asp & 3.76 & {$[26]$} \\
\hline & c. $4379 \mathrm{~T}>\mathrm{C}$ & p.Leu 1460Pro & 4.87 & {$[27]$} \\
\hline & c. $4447 \mathrm{~T}>\mathrm{C}$ & p.Cys1483Arg & $6.61-9.77$ & {$[26]$} \\
\hline & c. $6644 \mathrm{C}>\mathrm{T}$ & p.Ser2215Phe & 6.80 & [30] \\
\hline & c. $6644 \mathrm{C}>\mathrm{A}$ & p.Ser2215Tyr & 9.31 & {$[27]$} \\
\hline \multirow[t]{3}{*}{ HME } & c. $4448 \mathrm{C}>\mathrm{T}$ & p.Cys1483Tyr & 9.7 & {$[15]$} \\
\hline & c. $4448 \mathrm{C}>\mathrm{T}$ & p.Cys1483Tyr & 14 & {$[18]$} \\
\hline & c. $5005 \mathrm{G}>\mathrm{T}$ & p.Ala1669Ser & 44 & {$[18]$} \\
\hline
\end{tabular}

MCD, malformations of cortical development; FCD, focal cortical dysplasia; HME, hemimegalencephaly.

\section{Brain somatic mutations in MTOR}

\section{Phenotype and mutational spectrum}

Based on the discovery that neurodevelopmental disorders were caused by somatic mutations in genes of the PI3KAKT3 pathway, it was hypothesized that FCD might also be due to somatic mutations in genes belonging to the mTOR signalling cascade. Recent genetic studies have used high throughput sequencing with high coverage $(>100 \times)$ to investigate the underlying molecular genetic basis of FCD sporadic cases. Three reports performed deep whole-exome sequencing in blood-brain paired FCD samples and discovered mosaic missense variants in the MTOR gene in $12 / 77$ (15.6\%) individuals with FCD II [26], 6/13 (46\%) individuals with FCD IIb [27] and in one individual with FCD IIa [28]. Subsequently, Mirzaa et al. [29] identified MTOR somatic mosaic mutations in 4/42 (10\%) patients with FCD/HME and D'Gama et al. [18] reported mutations in 2/53 subjects with $\mathrm{FCD} / \mathrm{HME}$. Møller et al. [30] performed targeted ultra-deep sequencing (mean read depth of $2600 \times$ ), allowing the identification of low allele frequency $(0.9 \%$ to $6.8 \%)$ MTOR missense variants in 6/16 (37\%) subjects with FCD II. All brain somatic FCD- or HME-related MTOR variants published so far are listed in Table 2. 


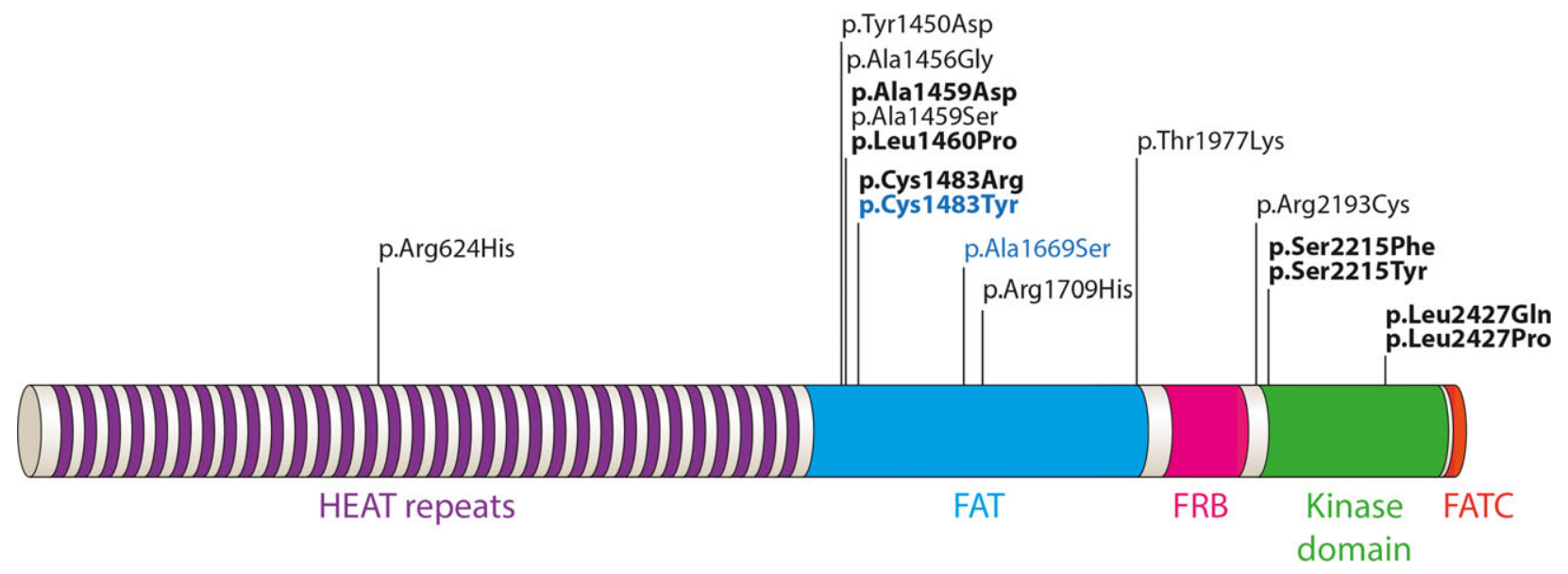

Figure 1. Schematic representation of the mechanistic target of rapamycin protein with the location of brain somatic variants reported in patients with focal cortical dysplasia (in black) and hemimegalencephaly (in blue). The location of the HEAT (huntingtin, elongation factor 3, protein phosphatase 2A) repeats, FAT (RAP, ATM, TRRAP) domain, rapamycin-biding domain (FRB), kinase domain, and FATC (FAT C-terminal) domain are indicated. Recurrent mutations are indicated in bold.

Overall, MTOR somatic variants were present at low rate mosaicism in brain DNA, with allele frequencies ranging from $0.93 \%$ to $12.63 \%$ in $\mathrm{FCD}$ II and from $9.7 \%$ to $44 \%$ in HME, and were not detected in the matched blood DNA (Table 2). The level of mosaicism of mutations was correlated with the extent of the brain malformation with a gradient ranging from low mosaic rates in FCD to higher rates in HME (Table 2). In addition, molecular analysis in two individuals with FCD IIa revealed a gradient of alternate allele fractions with an epicentre in the most epileptogenic area [29]. Interestingly, most MTOR variants were recurrent and reported across different studies: p.Ser2215Phe (eight times), p.Ser2215Tyr (five times), p.Leu1460Pro (four times), p.Cys1483Tyr (three times), p.Thr1977Lys (two times) and p.Leu2427Pro (two times). Most MTOR variants were located in the FAT and kinase domains of the protein (Figure 1).

In summary, brain mosaic MTOR mutations encompass a spectrum of MCD, from FCD IIa and IIb to HME. Somatic MTOR mutations account for $15.6-46 \%$ of FCD individuals across different cohorts and represent the most common genetic cause of FCD so far.

\section{Functional studies of MTOR mutations}

All MTOR brain mutations reported in individuals with FCD were missense, leading to a substitution of an amino acid in the protein. Since increased mTORC1 activity is thought to be the pathogenic mechanism underlying FCD, a gain-of-function was therefore hypothesized. Independent functional assays validated this hypothesis. Lim et al. (2015) achieved in vitro assessment of MTOR mutations in transfected HEK293T cells, and showed a subsequent increase of S6 and S6K phosphorylation levels. In vitro mTOR kinase assays further confirmed constitutive kinase activity for three mutants: p.Cys1483Arg, p.Leu2427Gln and p.Leu2427Pro [26]. In another study, Mirzaa et al. [29] performed functional studies on primary cultured neurons to demonstrate that MTOR mutations drive constitutive activation of the mTORC1 activity, leading to enlarged neuronal size. To test in vivo the pathogenicity of the recurrent p.Leu2427Pro MTOR variant, Lim et al. (2015) achieved a focal cortical expression of the mutant construct by in utero electroporation in the developing mouse brain at E14. The mouse model recapitulated most neuropathological features of FCD II patients, including migration effect, presence of cytomegalic neurons with mTORC1 hyperactivation, and emergence of spontaneous seizures [26]. Epilepsy and cytomegalic neurons were prevented by rapamycin treatment.

Studies in human brain specimens were also performed to assess mTORC1 activity. Immunostaining of postoperative tissue from individuals with somatic MTOR mutations showed histological evidence of mTORC1 signalling cascade activation with the presence of phospho-S6 positive cytomegalic neurons in FCD II or HME subjects [26-30]. Lim et al. showed by Sanger 
sequencing an enrichment of the mutant allele in microdissected cytomegalic phospho-S6 positive neurons from two FCD IIa subjects, confirming that MTOR variants act as activating variants leading to constitutive activation of the pathway [26]. Interestingly, most MTOR pathogenic variants are located in the FAT domain that structurally gives access to the mTOR kinase or in the kinase domain itself (Figure 1), suggesting that mutations affect important mTOR functional domains. Future studies should help resolve whether the type of mutation confers a given level of mTOR activation and therefore supports variable severity of the epileptogenic lesion.

\section{Germline mutations in GATOR1 genes}

\section{Phenotype and mutational spectrum}

A novel class of genes belonging to the amino acid sensing branch of the mTOR pathway has been

Table 3. Germline and somatic GATOR 1 mutations reported in the literature

\begin{tabular}{|c|c|c|c|c|}
\hline \multirow[b]{2}{*}{ MCD type } & \multirow[b]{2}{*}{ Gene } & \multicolumn{2}{|l|}{ Mutation } & \multirow[b]{2}{*}{ References } \\
\hline & & DNA (nucleotide change) & Protein (amino acid change) & \\
\hline FCD (suspicion) & $\begin{array}{l}\text { DEPDC5 } \\
D E P D C 5 \\
D E P D C 5\end{array}$ & $\begin{array}{l}\text { c. } 2390 \mathrm{del} A \\
\text { c. } 3994 \mathrm{C}>\mathrm{T} \\
\text { c. } 4260 \mathrm{delG}\end{array}$ & $\begin{array}{l}\text { p.Gln797Argfs*18 } \\
\text { p.Arg1332* } \\
\text { p.Glu1421Argfs*153 }\end{array}$ & $\begin{array}{l}{[39]} \\
{[40]} \\
{[41]}\end{array}$ \\
\hline FCD I & $\begin{array}{l}\text { DEPDC } 5 \\
D E P D C 5\end{array}$ & $\begin{array}{l}\text { c. } 1264 \mathrm{C}>\mathrm{T} \\
\text { c. } 715 \mathrm{C}>\mathrm{T} \text { (germline) } \\
\text { c. } 1264 \mathrm{C}>\mathrm{T} \text { (2-hit somatic) }\end{array}$ & $\begin{array}{l}\text { p.Arg422* } \\
\text { p.Arg239* } \\
\text { p.Arg422* }\end{array}$ & $\begin{array}{l}{[3]} \\
{[3]}\end{array}$ \\
\hline FCD Ia & NPRL2 & c.68_69delCT & p.Ile23Asnfs*6 & {$[41]$} \\
\hline FCD II (suspicion) & $\begin{array}{l}\text { DEPDC } 5 \\
D E P D C 5\end{array}$ & $\begin{array}{l}\text { c. } 715 \mathrm{C}>\mathrm{T} \\
\text { c. } 1759 \mathrm{C}>\mathrm{T}\end{array}$ & $\begin{array}{l}\text { p.Arg } 239^{*} \\
\text { p.Arg } 587^{*}\end{array}$ & $\begin{array}{l}2 \text { family-related patients [3] } \\
\text { [3] }\end{array}$ \\
\hline FCD II (BOSD) & $\begin{array}{l}D E P D C 5 \\
D E P D C 5\end{array}$ & $\begin{array}{l}\text { c. } 21 \mathrm{C}>\mathrm{G} \\
\text { c. } 418 \mathrm{C}>\mathrm{T}\end{array}$ & $\begin{array}{l}\text { p.Tyr7* } \\
\text { p.Gln } 140^{*}\end{array}$ & $\begin{array}{l}{[37]} \\
2 \text { family-related patients [37] }\end{array}$ \\
\hline FCD IIa & $\begin{array}{l}\text { DEPDC5 } \\
\text { DEPDC5 } \\
\text { DEPDC5 } \\
\text { DEPDC5 } \\
\text { NPRL3 } \\
\text { NPRL3 } \\
\text { NPRL3 } \\
\text { NPRL3 }\end{array}$ & $\begin{array}{l}\text { c. } 1759 \mathrm{C}>\mathrm{T} \\
\text { c. } 1663 \mathrm{C}>\mathrm{T} \\
\text { c. } 484-1 \mathrm{G}>\mathrm{A} \\
\text { c. } 842 \mathrm{~A}>\mathrm{T} \\
\text { c. } 1375 \_1376 \text { dupAC } \\
\text { c. } 275 \mathrm{G}>\mathrm{A} \\
\text { c. } 1270 \mathrm{C}>\mathrm{T} \\
\text { c. } 1352-4 \text { delACAGInsTGACCCATCC }\end{array}$ & $\begin{array}{l}\text { p.Arg587* } \\
\text { p.Arg555* } \\
\text { p.(?) } \\
\text { p.Tyr281Phe } \\
\text { p.Ser460Profs*20 } \\
\text { p.Arg92Gln } \\
\text { p.Arg424* } \\
\text { p.(?) }\end{array}$ & $\begin{array}{l}{[3]} \\
2 \text { family-related patients [38] } \\
{[3]} \\
{[39]} \\
2 \text { family-related patients [43] } \\
{[43]} \\
{[41]} \\
{[43]}\end{array}$ \\
\hline FCD IIb & $\begin{array}{l}\text { DEPDC5 } \\
\text { DEPDC5 } \\
\text { DEPDC5 } \\
\text { NPRL3 }\end{array}$ & $\begin{array}{l}\text { c. } 624+1 \mathrm{G}>\mathrm{A} \\
\text { c.1218-18_1218-15delTGTT } \\
\text { c. } 783 \text { 786delTGAG } \\
\text { c.1070delC }\end{array}$ & $\begin{array}{l}\text { p.(?) } \\
\text { p.(?) } \\
\text { p.Asn261Lysfs*11 } \\
\text { p.Pro357Hisfs*56 }\end{array}$ & $\begin{array}{l}{[18]} \\
{[18]} \\
{[18]} \\
{[41]}\end{array}$ \\
\hline HME & $\begin{array}{l}D E P D C 5 \\
D E P D C 5\end{array}$ & $\begin{array}{l}\text { c. } 128 \_129 \mathrm{insC} \\
\text { c. } 1265 \mathrm{G}>\mathrm{A}\end{array}$ & $\begin{array}{l}\text { p.Asn } 45 \mathrm{Glnfs} * 3 \\
\text { p.Arg } 422 \mathrm{Gln}\end{array}$ & $\begin{array}{l}{[18]} \\
{[18]}\end{array}$ \\
\hline HME (histology FCD IIa) & DEPDC 5 & $\begin{array}{l}\text { c. } 4187 \text { delC (saliva }(28 \%) \\
\text { and brain }(35 \%) \text { mosaic) }\end{array}$ & p.Ala1396Valfs* 78 & [29] \\
\hline Band heterotopia & DEPDC5 & c. $279+1 \mathrm{G}>\mathrm{A}$ & p.(?) & {$[37]$} \\
\hline PMG & NPRL2 & c. $329 \mathrm{C}>\mathrm{G}$ & p.Thr110Ser & [40] \\
\hline Bilateral PMG & DEPDC5 & c. $3696+5 \mathrm{G}>\mathrm{A}$ & p.(?) & {$[40]$} \\
\hline Unilateral pachygyria & DEPDC 5 & c.4689_4690delAG & p.Asp1565* & {$[42]$} \\
\hline
\end{tabular}

MCD, malformations of cortical development; FCD, focal cortical dysplasia; HME, hemimegalencephaly; BOSD, bottom of sulcus dysplasia; PMG, polymicrogyria; suspicion, malformation diagnosis established on MRI features in the absence of histology data. 
involved in inherited focal epilepsies: DEPDC5 (Dishevelled, Egl-10 and pleckstrin domain containing protein 5), NPRL2 (nitrogene permease regulator-like 2) and NPRL3 (nitrogene permease regulator-like 3) [31,32]. All three proteins form the GATOR1 complex (GAP Activity Toward Rags complex 1), which functions as an inhibitor of mTORC1 both in mammalian cells [33] and in yeast [34,35]. Loss-of-function mutations in GATOR1 genes are the most frequent genetic cause of inherited focal epilepsies, including monogenic entities such as familial focal epilepsy with variable foci, autosomal dominant nocturnal frontal lobe epilepsy also called sleep-related hypermotor epilepsy or familial temporal lobe epilepsy [36]. An important clinical feature of the GATOR1-related epilepsies is the prevalence of individuals with MCDs such as FCD IIa and IIb or HME [3,37].

In this section, we review the MCD subtypes of published cases with germline mutations in GATOR 1 genes (DEPDC5, NPRL2 or NPRL3). In total, we listed 32 subjects with a focal epilepsy associated to an MCD detected by MRI or histopathological analysis, including FCD Ia, FCD IIa, FCD IIb to HME, band heterotopia, polymicrogyria or unilateral pachygyria $[3,18,29,37-$ 42] (Table 3). Among the 28 distinct variants reported, 24 were null variants, leading to a premature Stop codon and four were missense variants of unknown pathogenicity due to the lack of functional assays. Evidence of nonsense mediated decay degradation of the DEPDC5, NPRL2 or NPRL3 transcripts with premature Stop codons was provided either in cultured lymphoblasts from patients $[32,41]$ or in FCD IIa postoperative cerebral tissue [43]. Since the majority of mutations lead to haploinsufficiency, the molecular mechanism is likely to be a loss-of-function [36].

The role of inherited germline variants in the aetiology of FCD is nevertheless enigmatic, since only a portion of epilepsy affected DEPDC5 variant carriers develops FCD, whereas others have nonlesional focal epilepsy. The observation that only a subset of cells, i.e. balloon cells and dysmorphic neurons, display increased S6 phosphorylation suggests a mosaic inactivation of GATOR1 gene(s). It is therefore difficult to conceptualize how a germline mutation can sustain a focal and mosaic pattern as observed in FCD. Because DEPDC5 is a repressor of mTORC1, we speculate that a double-hit inactivation in brain cells is necessary to generate FCD. An exciting hypothesis is therefore that a DEPDC5 germline loss-of-function mutation together with a second somatic hit in DEPDC5, leading to biallelic inactivation, might be responsible for the development of the FCD, a mechanism known as Knudson's two-hit mechanism initially described in cancer [44]. In 2015, Baulac et al. [3] detected by Sanger sequencing a somatic nonsense variant in the lesional resected brain tissue from an individual with FCD IIa and a familial history of focal epilepsy due to a germline mutation in DEPDC5, suggesting a biallelic inactivation. Further studies are needed to definitively validate the presence of a second-hit somatic loss-of-function mutation in negative regulators of the mTOR pathway such as DEPDC5, NPRL2 or NPRL3. Two-hit mechanism has been suspected in tubers from TSC syndrome patients with multiple hamartomas and renal angiomyolipoma, neoplastic tissues in which somatic mutations accumulate [45].

\section{Functional studies and animal models of GATOR1}

Since GATOR1 inhibits mTORC1 activity in amino acid deprivation conditions, loss-of-function mutations in GATOR1 genes are predicted to result in excessive mTORC1 kinase activity. Several studies investigated by immunohistochemistry the phosphorylation levels of mTORC1 substrate S6 on postoperative brain tissue from individuals mutated in GATOR1 genes. Increased levels of S6 phosphorylation were observed in individuals with FCD Ia, FCD IIa, and HME with a histopathology of FCD IIa $[29,38,41,43]$ confirming that pathogenic variants in GATOR1 genes are the cause of the mTORC1 hyperactivity observed in these FCD and HME cases.

Constitutive KO rodent models of the three GATOR1 genes (Depdc5, Nprl2, Nprl3) have been generated in mice and rats. All homozygous animals, $\mathrm{Nprl}^{-/-}$mice [46], $\mathrm{Nprl}^{-1-}$ mice [47], Depdc5 $5^{-/-}$rats [48] and Depdc $5^{-1-}$ mice [49] are embryonic lethal, demonstrating that GATOR1 has a crucial role in embryonic development. Marsan et al. [48] showed that mTORC1 is hyperactivated in Depdc5 $5^{-1-}$ rats and that a single prenatal injection of rapamycin could rescue their global growth delay, demonstrating that embryonic lethality is caused by mTORC1 hyperactivation. Hughes et al. [49] confirmed mTORC1 hyperactivity in Depdc $5^{-1-}$ mice and reported blood and lymphatic vascular defects underlying embryonic lethality. Heterozygous KO animals of 


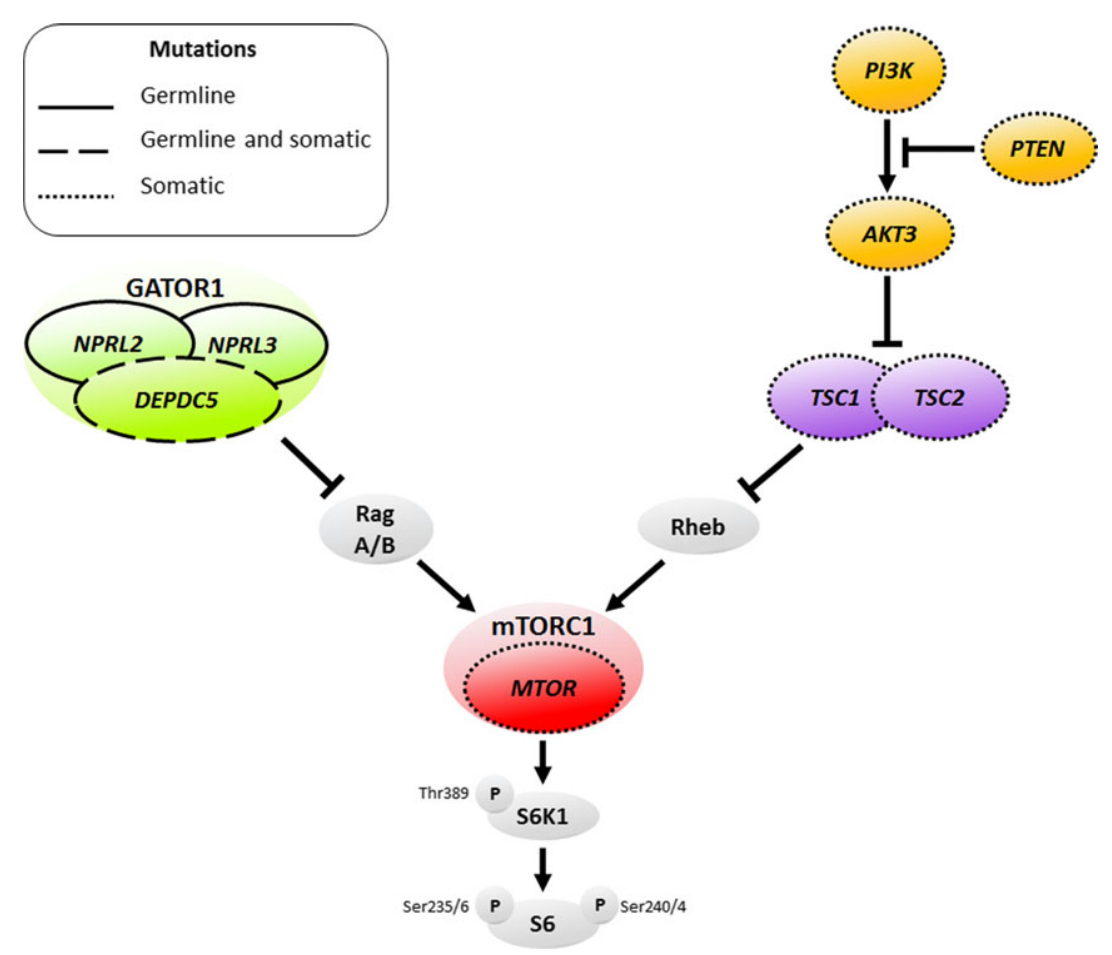

Figure 2. Mutations in genes of the mechanistic target of rapamycin (mTOR) pathway responsible for focal cortical dysplasia (FCD) and hemimegalencephaly (HME). Germline and somatic mutation in the mTOR complex 1 (mTORC1) pathway cause FCD and HME. Germline mutations in GATOR1 genes have been reported in FCD and HME, as well as a two-hit in DEPDC5 in an FCD patient. Moreover, brain somatic mutations have also been reported in PIK3CA, AKT3, PTEN and MTOR. TSC, tuberous sclerosis complex.

GATOR1 genes were also investigated. Epileptic activity was not assessed in $\mathrm{Nprl}^{+/-}[46]$ and $\mathrm{Nprl3}^{+/-}[47]$ mice, suggesting that spontaneous seizures did not occur. Similarly, heterozygous Depdc $5^{+/-}$rats and Depdc $5^{+/-}$mice did not have spontaneous epileptic seizures $[48,49]$. However, Depdc $5^{+/-}$rats presented subtle and diffuse cortical malformations reminiscent of FCD type IIb: (i) cortical boundaries between layers I/II and V/VI were less recognizable, (ii) few balloon-like cells characterized by a round shape translucent cytoplasm and peripheral nucleus and (iii) dysmorphic neurons with increased phosphorylation of S6 protein indicating hyperactivation of mTORC1. Marsan et al. [48] study further reported that prenatal administration of rapamycin can improve the cortical malformations.

In a recent study, Yuskaitis et al. reported a neuronspecific Depdc5 conditional KO mouse model by Cre recombination under the Synapsin1 promotor. Depd$c 5^{\text {flox/flox }}$-Syn1Cre mice survived to adulthood and presented larger brains with dysplastic neurons throughout the cortex with mTORC1 hyperactivation. A fraction of mice exhibited spontaneous clinical seizures and lowered seizure thresholds to pentylenetetrazol-induced seizures [50].

\section{Conclusions}

Recent genetic studies have established a major role of brain somatic mutations in genes of the mTOR pathway in the aetiology of focal MCD. These findings have revealed the existence of a genetic continuum between FCD subtypes (I, IIa and IIb) and HME, showing shared molecular biomarkers belonging to the mTOR pathway. These observations suggested that FCD and HME represent a spectrum of neurodevelopmental disorders resulting from distinct timing and cell type progenitors in which the mutation occurred during brain development (Figure 2). One can expect that a mutation occurring early during the development would affect a large number of cells and result in a larger malformation such as an HME, whereas the same mutation occurring later in neurodevelopment would cause a smaller focal malformation such as an FCD II; a mutation occurring during the postmigration stage would cause a FCD I [51]. We 


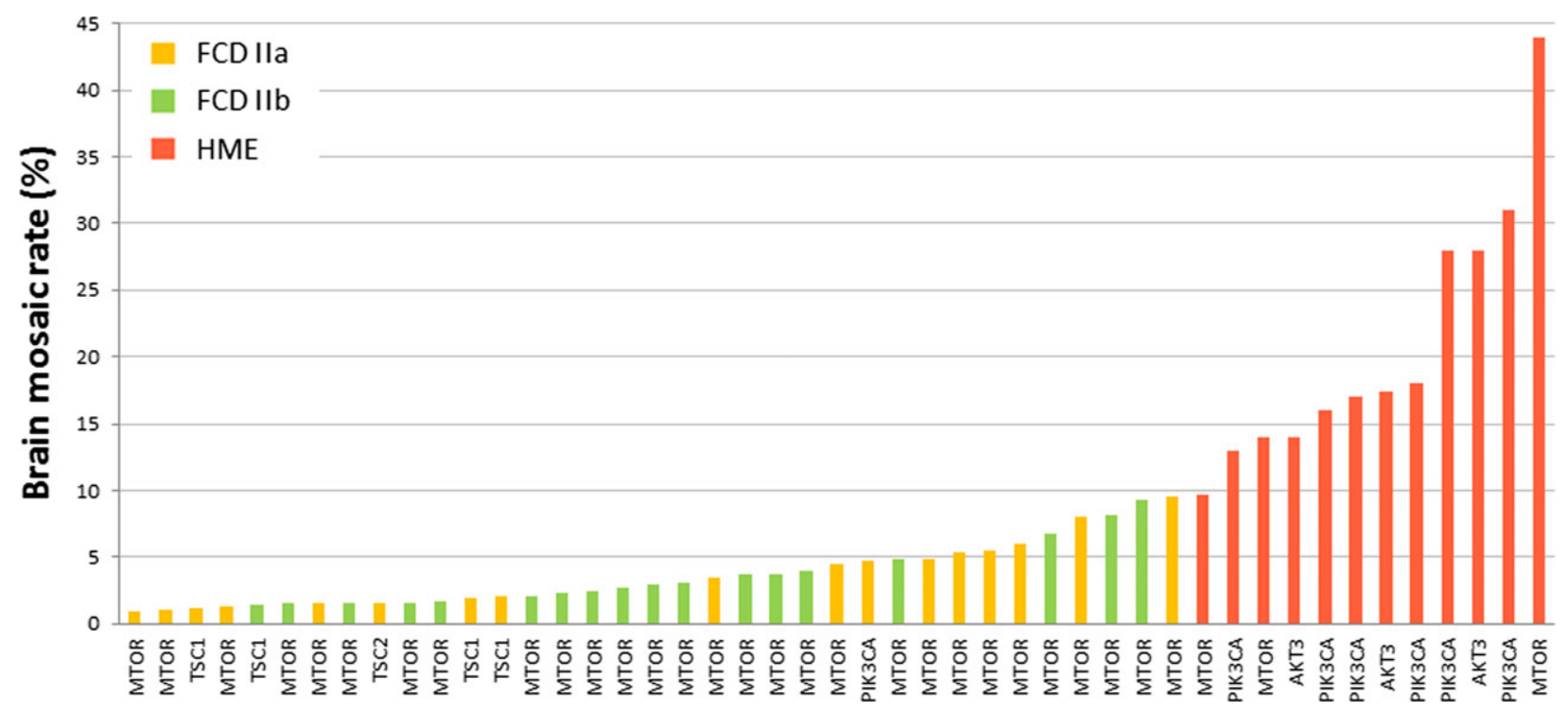

Figure 3. Brain mosaic rate of mutations in mTOR pathway genes are correlated with the malformations of cortical development subtype. All variants listed in Tables 1-3 are represented in the graph. When the mosaic rate was provided as a range, we considered the mean values in the graph; when the allele frequency was not provided, the variant is not shown. Focal cortical dysplasia (FCD) IIa and FCD IIb present a brain mosaic rate ranging from $0.93 \%$ to $9.31 \%$ (average of 3.6\%), whereas hemimegalencephaly (HME) brain mosaic rate varies from $9.7 \%$ to $44 \%$ (average of $20.8 \%$.).

reviewed the literature and illustrate in Figure 3 the correlation between the mutational mosaic rate and the extent of the brain lesion, considering collectively all mutated genes. A higher percentage of cells with a mutation is observed in HME (alternative allelic fraction range: $9.7-44 \%$, mean: $20.8 \%$ ) than in FCD IIa (alternative allelic fraction range: $0.93-9.6 \%$, mean: $3.7 \%$ ) or FCD IIb (alternative allelic fraction range: 1.379.31\%, mean: $3.5 \%$ ). The degree of mosaicism was similar between FCD IIa and IIb. Hence, the origin of balloon cells found exclusively in FCD IIb remains enigmatic. Since conventional sequencing techniques such as Sanger do not allow the detection of low allele frequency variants $(<10 \%)$, technologies with higher sensitivity achieving deep sequencing coverage combined to specific bioinformatics tools are needed to detect such variants. In the future, numerous somatic mutations in known or novel genes will undoubtedly be unveiled in resected brain specimens from apparently negative FCD cases. Possible genotype-phenotype correlations might emerge, allowing genetic clinical diagnosis to help predict patient outcome.

Activating somatic mutations in the MTOR gene account for $15.6-46 \%$ of FCD cases and represent the most common known cause of this disorder so far. Moreover, activating somatic mutations in AKT3 and
PIK3CA genes are mostly encountered in HME accounting for $17-33 \%$ of patients $[14,15,17,18]$. In contrast, only few somatic variants in mTORC1 inhibitor genes (TSC1, TSC2, DEPDC5) have been reported so far in FCD (Tables 1 and 3). While gain-of-function mutations in mTOR activator genes (AKT3 or PIK3CA) or MTOR gene itself are single mutational events, lossof-function mutations in mTORC1 inhibitors such as DEPDC5 are likely to necessitate a biallelic inactivation to cause dysplasia. Improvement in sequencing technologies allowing single-cell sequencing and ultradeep sequencing will likely unveil more examples of doublehit - germline and somatic - mutations in the future.

Like TSC syndrome, FCD belongs to the mTORopathy group of neurodevelopmental disorders, a term introduced to describe neurological disorders characterized by altered cortical architecture, abnormal neuronal morphology and intractable epilepsy. How loss-of-function mutations in mTORC1 inhibitor genes or gain-offunction mutations in mTORC1 activator genes or MTOR gene itself lead to mTORC1 hyperactivation is still unknown. mTOR is a kinase that phosphorylates numerous substrates among which the protein S6 that controls cell growth. In pathological conditions, when S6 is hyperphosphorylated, protein synthesis is increased leading to enlarged cells. Cepeda and 
colleagues have studied the role of these abnormal cells in epileptogenesis. They demonstrated in organotypic slices from FCD resected tissue that balloon cells are hypoexcitable and thus might not initiate any epileptic activity, whereas dysmorphic pyramidal neurons and cytomegalic interneurons are hyperexcitable. Therefore, cytomegalic neurons may have a major role in the generation and propagation of epileptic discharges [52]. Hence, mTOR signalling cascade hyperactivation is likely to provide necessary grounds for epileptogenesis, but the different molecular actors involved in the transduction of signal linking mTOR hyperactivation to neuronal hyperexcitability still remains to be elucidated.

Importantly, mTORC1 can be pharmacologically targeted by derivatives of rapamycin and has been proven to be partially efficient for controlling seizures in TSC syndrome [53]. Rapamycin treatment prevent brain malformations and epilepsy in animal models, suggesting that inhibition of the mTORC1 pathway could be of interest as a new therapeutic target in patients with FCD or HME related to mTOR pathway genes.

\section{Acknowledgements}

Elise Marsan and Stéphanie Baulac wrote the review. We thank Théo Ribierre for critical reading of the article, and the Fondation pour la Recherche Médicale (FDT20160736468 to EM), the programme 'Investissements d'avenir' ANR-10-IAIHU-06 (to EM) and the European Research Council (ERC 682345 to SB).

\section{References}

1 Blumcke I, Thom M, Aronica E, Armstrong DD, Vinters HV, Palmini A, Jacques TS, Avanzini G, Barkovich AJ, Battaglia G, Becker A, Cepeda C, Cendes F, Colombo N, Crino P, Cross JH, Delalande O, Dubeau F, Duncan J, Guerrini R, Kahane P, Mathern G, Najm I, Ozkara C, Raybaud C, Represa A, Roper SN, Salamon N, SchulzeBonhage A, Tassi L, Vezzani A, Spreafico R. The clinicopathologic spectrum of focal cortical dysplasias: a consensus classification proposed by an ad hoc task force of the ILAE diagnostic methods commission. Epilepsia 2011; 52: 158-74

2 Leventer RJ, Jansen FE, Mandelstam SA, Ho A, Mohamed I, Sarnat HB, Kato M, Fukasawa T, Saitsu H, Matsumoto N, Itoh M, Kalnins RM, Chow CW, Harvey AS, Jackson GD, Crino PB, Berkovic SF, Scheffer IE. Is focal cortical dysplasia sporadic? Family evidence for genetic susceptibility Epilepsia 2014; 55: e22-6
3 Baulac S, Ishida S, Marsan E, Miquel C, Biraben A, Nguyen DK, Nordli D, Cossette P, Nguyen S, Lambrecq V, Vlaicu M, Daniau M, Bielle F, Andermann E, Andermann F, Leguern E, Chassoux F, Picard F. Familial focal epilepsy with focal cortical dysplasia due to DEPDC5 mutations. Ann Neurol 2015; 77: 675-83

4 Laplante M, Sabatini DM. mTOR signaling in growth control and disease. Cell 2012; 149: 274-93

5 Saxton RA, Sabatini DM. mTOR signaling in growth, metabolism, and disease. Cell 2017; 169: 361-71

6 Baybis M, Yu J, Lee A, Golden JA, Weiner H, McKhann G 2nd, Aronica E, Crino PB. mTOR cascade activation distinguishes tubers from focal cortical dysplasia. Ann Neurol 2004; 56: 478-87

7 Miyata H, Chiang AC, Vinters HV. Insulin signaling pathways in cortical dysplasia and TSC-tubers: tissue microarray analysis. Ann Neurol 2004; 56: 510-19

8 Ljungberg MC, Bhattacharjee MB, Lu Y, Armstrong DL, Yoshor D, Swann JW, Sheldon M, D'Arcangelo G. Activation of mammalian target of rapamycin in cytomegalic neurons of human cortical dysplasia. Ann Neurol 2006; 60: 420-9

9 Liu J, Reeves C, Michalak Z, Coppola A, Diehl B, Sisodiya SM, Thom M. Evidence for mTOR pathway activation in a spectrum of epilepsy-associated pathologies. Acta Neuropathol Commun 2014; 2: 71

10 Aronica E, Crino PB. Epilepsy related to developmental tumors and malformations of cortical development. Neurotherapeutics: the journal of the American Society for Experimental. Neurotherapeutics 2014; 11: 251-68

11 Mirzaa GM, Poduri A. Megalencephaly and hemimegalencephaly: breakthroughs in molecular etiology. Am J Med Genet C Semin Med Genet 2014; 166C: 156-72

12 Poduri A, Evrony GD, Cai X, Walsh CA. Somatic mutation, genomic variation, and neurological disease. Science 2013; 341: 1237758

13 Schick V, Majores M, Engels G, Spitoni S, Koch A, Elger CE, Simon M, Knobbe C, Blumcke I, Becker AJ. Activation of Akt independent of PTEN and CTMP tumor-suppressor gene mutations in epilepsy-associated Taylor-type focal cortical dysplasias. Acta Neuropathol 2006; 112: 715-25

14 Poduri A, Evrony GD, Cai X, Elhosary PC, Beroukhim R, Lehtinen MK, Hills LB, Heinzen EL, Hill A, Hill RS, Barry BJ, Bourgeois BF, Riviello JJ, Barkovich AJ, Black PM, Ligon KL, Walsh CA. Somatic activation of AKT3 causes hemispheric developmental brain malformations. Neuron 2012; 74: 41-8

15 Lee JH, Huynh M, Silhavy JL, Kim S, Dixon-Salazar T, Heiberg A, Scott E, Bafna V, Hill KJ, Collazo A, Funari V, Russ C, Gabriel SB, Mathern GW, Gleeson JG. De novo somatic mutations in components of the PI3KAKT3-mTOR pathway cause hemimegalencephaly. Nat Genet 2012; 44: 941-5

16 Conti V, Pantaleo M, Barba C, Baroni G, Mei D, Buccoliero AM, Giglio S, Giordano F, Baek ST, Gleeson JG, 
Guerrini R. Focal dysplasia of the cerebral cortex and infantile spasms associated with somatic 1q21.1-q44 duplication including the AKT3 gene. Clin Genet 2015; 88: $241-7$

17 Jansen LA, Mirzaa GM, Ishak GE, O’Roak BJ, Hiatt JB, Roden WH, Gunter SA, Christian SL, Collins S, Adams C, Riviere JB, St-Onge J, Ojemann JG, Shendure J, Hevner RF, Dobyns WB. PI3K/AKT pathway mutations cause a spectrum of brain malformations from megalencephaly to focal cortical dysplasia. Brain 2015; 138 (Pt. 6): 1613-28

18 D'Gama AM, Geng Y, Couto JA, Martin B, Boyle EA, LaCoursiere CM, Hossain A, Hatem NE, Barry BJ, Kwiatkowski DJ, Vinters HV, Barkovich AJ, Shendure J, Mathern GW, Walsh CA, Poduri A. Mammalian target of rapamycin pathway mutations cause hemimegalencephaly and focal cortical dysplasia. Ann Neurol 2015; 77: 720-5

19 Lim JS, Gopalappa R, Kim SH, Ramakrishna S, Lee M, Kim WI, Kim J, Park SM, Lee J, Oh JH, Kim HD, Park CH, Lee JS, Kim S, Kim DS, Han JM, Kang HC, Kim HH, Lee JH. Somatic mutations in TSC1 and TSC2 cause focal cortical dysplasia. Am J Hum Genet 2017; 100: 454-72

20 Feliciano DM, Su T, Lopez J, Platel JC, Bordey A. Single-cell Tsc1 knockout during corticogenesis generates tuber-like lesions and reduces seizure threshold in mice. J Clin Invest 2011; 121: 1596-607

21 Tsai V, Parker WE, Orlova KA, Baybis M, Chi AW, Berg BD, Birnbaum JF, Estevez J, Okochi K, Sarnat HB, Flores-Sarnat L, Aronica E, Crino PB. Fetal brain mTOR signaling activation in tuberous sclerosis complex. Cereb Cortex 2014; 24: 315-27

22 Baek ST, Copeland B, Yun EJ, Kwon SK, Guemez-Gamboa A, Schaffer AE, Kim S, Kang HC, Song S, Mathern GW, Gleeson JG. An AKT3-FOXG1-reelin network underlies defective migration in human focal malformations of cortical development. Nat Med 2015; 21: 1445-54

23 Meikle L, Talos DM, Onda H, Pollizzi K, Rotenberg A, Sahin M, Jensen FE, Kwiatkowski DJ. A mouse model of tuberous sclerosis: neuronal loss of Tsc1 causes dysplastic and ectopic neurons, reduced myelination, seizure activity, and limited survival. J Neurosci 2007; 27: $5546-58$

24 Goto J, Talos DM, Klein P, Qin W, Chekaluk YI, Anderl S, Malinowska IA, Di Nardo A, Bronson RT, Chan JA, Vinters HV, Kernie SG, Jensen FE, Sahin M, Kwiatkowski DJ. Regulable neural progenitor-specific Tsc1 loss yields giant cells with organellar dysfunction in a model of tuberous sclerosis complex. Proc Natl Acad Sci USA 2011; 108: E1070-9

25 Roy A, Skibo J, Kalume F, Ni J, Rankin S, Lu Y, Dobyns WB, Mills GB, Zhao JJ, Baker SJ, Millen KJ. Mouse models of human PIK3CA-related brain overgrowth have acutely treatable epilepsy. Elife 2015; 4: e12703

26 Lim JS, Kim WI, Kang HC, Kim SH, Park AH, Park EK, Cho YW, Kim S, Kim HM, Kim JA, Kim J, Rhee H,
Kang SG, Kim HD, Kim D, Kim DS, Lee JH. Brain somatic mutations in MTOR cause focal cortical dysplasia type II leading to intractable epilepsy. Nat Med 2015; 21: 395-400

27 Nakashima M, Saitsu H, Takei N, Tohyama J, Kato M, Kitaura H, Shiina M, Shirozu H, Masuda H, Watanabe K, Ohba C, Tsurusaki Y, Miyake N, Zheng Y, Sato T, Takebayashi H, Ogata K, Kameyama S, Kakita A, Matsumoto N. Somatic mutations in the MTOR gene cause focal cortical dysplasia type IIb. Ann Neurol 2015; 78: 375-86

28 Leventer RJ, Scerri T, Marsh AP, Pope K, Gillies G, Maixner W, MacGregor D, Harvey AS, Delatycki MB, Amor DJ, Crino P, Bahlo M, Lockhart PJ. Hemispheric cortical dysplasia secondary to a mosaic somatic mutation in MTOR. Neurology 2015; 84: 2029-32

29 Mirzaa GM, Campbell CD, Solovieff N, Goold C, Jansen LA, Menon S, Timms AE, Conti V, Biag JD, Adams C, Boyle EA, Collins S, Ishak G, Poliachik S, Girisha KM, Yeung KS, Chung BHY, Rahikkala E, Gunter SA, McDaniel SS, Macmurdo CF, Bernstein JA, Martin B, Leary R, Mahan S, Liu S, Weaver M, Doerschner M, Jhangiani S, Muzny DM, Boerwinkle E, Gibbs RA, Lupski JR, Shendure J, Saneto RP, Novotny EJ, Wilson CJ, Sellers WR, Morrissey M, Hevner RF, Ojemann JG, Guerrini R, Murphy LO, Winckler W, Dobyns WB. Association of MTOR mutations with developmental brain disorders, including megalencephaly, focal cortical dysplasia, and pigmentary mosaicism. JAMA Neurol 2016; 73: 836-45

30 Moller RS, Weckhuysen S, Chipaux M, Marsan E, Taly V, Bebin EM, Hiatt SM, Prokop JW, Bowling KM, Mei D, Conti V, de la Grange P, Ferrand-Sorbets S, Dorfmuller G, Lambrecq V, Larsen LH, Leguern E, Guerrini R, Rubboli G, Cooper GM, Baulac S. Germline and somatic mutations in the MTOR gene in focal cortical dysplasia and epilepsy. Neurol Genet 2016; 2: e118

31 Dibbens LM, de Vries B, Donatello S, Heron SE, Hodgson BL, Chintawar S, Crompton DE, Hughes JN, Bellows ST, Klein KM, Callenbach PM, Corbett MA, Gardner AE, Kivity S, Iona X, Regan BM, Weller CM, Crimmins D, O'Brien TJ, Guerrero-Lopez R, Mulley JC, Dubeau F, Licchetta L, Bisulli F, Cossette P, Thomas PQ, Gecz J, Serratosa J, Brouwer OF, Andermann F, Andermann E, van den Maagdenberg AM, Pandolfo M, Berkovic SF, Scheffer IE. Mutations in DEPDC5 cause familial focal epilepsy with variable foci. Nat Genet 2013; 45: 546-51

32 Ishida S, Picard F, Rudolf G, Noe E, Achaz G, Thomas P, Genton P, Mundwiller E, Wolff M, Marescaux C, Miles R, Baulac M, Hirsch E, Leguern E, Baulac S. Mutations of DEPDC5 cause autosomal dominant focal epilepsies. Nat Genet 2013; 45: 552-5

33 Bar-Peled L, Chantranupong L, Cherniack AD, Chen WW, Ottina KA, Grabiner BC, Spear ED, Carter SL, Meyerson M, Sabatini DM. A tumor suppressor complex with GAP activity for the Rag GTPases that signal 
amino acid sufficiency to mTORC1. Science 2013; 340: 1100-6

34 Panchaud N, Peli-Gulli MP, De Virgilio C. Amino acid deprivation inhibits TORC1 through a GTPase-activating protein complex for the rag family GTPase Gtr1. Science Signaling 2013; 6: ra42.

35 Algret R, Fernandez-Martinez J, Shi Y, Kim SJ, Pellarin R, Cimermancic P, Cochet E, Sali A, Chait BT, Rout MP, Dokudovskaya S. Molecular architecture and function of the SEA complex, a modulator of the TORC1 pathway. Mol Cell Proteomics 2014; 13: 2855-70

36 Baulac S. mTOR signaling pathway genes in focal epilepsies. Prog Brain Res 2016; 226: 61-79

37 Scheffer IE, Heron SE, Regan BM, Mandelstam S, Crompton DE, Hodgson BL, Licchetta L, Provini F, Bisulli F, Vadlamudi L, Gecz J, Connelly A, Tinuper P, Ricos MG, Berkovic SF, Dibbens LM. Mutations in mammalian target of rapamycin regulator DEPDC5 cause focal epilepsy with brain malformations. Ann Neurol 2014; 75: 782-7

38 Scerri T, Riseley JR, Gillies G, Pope K, Burgess R, Mandelstam SA, Dibbens L, Chow CW, Maixner W, Harvey AS, Jackson GD, Amor DJ, Delatycki MB, Crino PB, Berkovic SF, Scheffer IE, Bahlo M, Lockhart PJ, Leventer RJ. Familial cortical dysplasia type IIA caused by a germline mutation in DEPDC5. Ann Clin Transl Neurol 2015; 2: 575-80

39 Carvill GL, Crompton DE, Regan BM, McMahon JM, Saykally J, Zemel M, Schneider AL, Dibbens L, Howell KB, Mandelstam S, Leventer RJ, Harvey AS, Mullen SA, Berkovic SF, Sullivan J, Scheffer IE, Mefford HC. Epileptic spasms are a feature of DEPDC5 mTORopathy. Neurol Genet 2015; 1: e17

40 Ricos MG, Hodgson BL, Pippucci T, Saidin A, Ong YS, Heron SE, Licchetta L, Bisulli F, Bayly MA, Hughes J, Baldassari S, Palombo F; Epilepsy Electroclinical Study G, Santucci M, Meletti S, Berkovic SF, Rubboli G, Thomas PQ, Scheffer IE, Tinuper P, Geoghegan J, Schreiber AW, Dibbens LM. Mutations in the mammalian target of rapamycin pathway regulators NPRL2 and NPRL3 cause focal epilepsy. Ann Neurol 2016; 79: 120-31.

41 Weckhuysen S, Marsan E, Lambrecq V, Marchal C, Morin-Brureau M, An-Gourfinkel I, Baulac M, Fohlen M, Kallay Zetchi C, Seeck M, de la Grange P, Dermaut B, Meurs A, Thomas P, Chassoux F, Leguern E, Picard F, Baulac S. Involvement of GATOR complex genes in familial focal epilepsies and focal cortical dysplasia. Epilepsia 2016; 57: 994-1003

42 Cen Z, Guo Y, Lou Y, Jiang B, Wang J, Feng J. De novo mutation in DEPDC5 associated with unilateral pachygyria and intractable epilepsy. Seizure 2017; 50: 1-3

43 Sim JC, Scerri T, Fanjul-Fernandez M, Riseley JR, Gillies G, Pope K, van Roozendaal H, Heng JI, Mandelstam SA, McGillivray G, MacGregor D, Kannan L, Maixner W, Harvey AS, Amor DJ, Delatycki MB, Crino PB, Bahlo M, Lockhart PJ, Leventer RJ. Familial cortical dysplasia caused by mutation in the mammalian target of rapamycin regulator NPRL3. Ann Neurol 2016; 79: 132-7

44 Knudson AG Jr. Mutation and cancer: statistical study of retinoblastoma. Proc Natl Acad Sci USA 1971; 68: 820-3

45 Qin W, Chan JA, Vinters HV, Mathern GW, Franz DN, Taillon BE, Bouffard P, Kwiatkowski DJ. Analysis of TSC cortical tubers by deep sequencing of TSC1, TSC2 and KRAS demonstrates that small second-hit mutations in these genes are rare events. Brain Pathol 2010; 20: 1096-105

46 Dutchak PA, Laxman S, Estill SJ, Wang C, Wang Y, Wang Y, Bulut GB, Gao J, Huang LJ, Tu BP. Regulation of hematopoiesis and methionine homeostasis by mTORC1 inhibitor NPRL2. Cell Rep 2015; 12: 371-9

47 Kowalczyk MS, Hughes JR, Babbs C, Sanchez-Pulido L, Szumska D, Sharpe JA, Sloane-Stanley JA, Morriss-Kay GM, Smoot LB, Roberts AE, Watkins H, Bhattacharya S, Gibbons RJ, Ponting CP, Wood WG, Higgs DR. $\mathrm{Nprl3}$ is required for normal development of the cardiovascular system. Mamm Genome 2012; 23: 404-15

48 Marsan E, Ishida S, Schramm A, Weckhuysen S, Muraca G, Lecas S, Liang N, Treins C, Pende M, Roussel D, Le Van QM, Mashimo T, Kaneko T, Yamamoto T, Sakuma T, Mahon S, Miles R, Leguern E, Charpier S, Baulac S. Depdc5 knockout rat: a novel model of mTORopathy. Neurobiol Dis 2016; 89: 180-9

49 Hughes J, Dawson R, Tea M, McAninch D, Piltz S, Jackson D, Stewart L, Ricos MG, Dibbens LM, Harvey NL, Thomas P. Knockout of the epilepsy gene Depdc 5 in mice causes severe embryonic dysmorphology with hyperactivity of mTORC1 signalling. Sci Rep 2017; 7: 12618

50 Yuskaitis CJ, Jones BM, Wolfson RL, Super CE, Dhamne SC, Rotenberg A, Sabatini DM, Sahin M, Poduri A. A mouse model of DEPDC5-related epilepsy: neuronal loss of Depdc5 causes dysplastic and ectopic neurons, increased mTOR signaling, and seizure susceptibility. Neurobiol Dis 2017; 111: 91-101

51 Barkovich AJ, Guerrini R, Kuzniecky RI, Jackson GD, Dobyns WB. A developmental and genetic classification for malformations of cortical development: update 2012. Brain 2012; 135(Pt. 5): 1348-69

52 Abdijadid S, Mathern GW, Levine MS, Cepeda C. Basic mechanisms of epileptogenesis in pediatric cortical dysplasia. CNS Neurosci Ther 2015; 21: 92-103

53 French JA, Lawson JA, Yapici Z, Ikeda H, Polster T, Nabbout R, Curatolo P, de Vries PJ, Dlugos DJ, Berkowitz N, Voi M, Peyrard S, Pelov D, Franz DN. Adjunctive everolimus therapy for treatment-resistant focal-onset seizures associated with tuberous sclerosis (EXIST-3): a phase 3, randomised, double-blind, placebo-controlled study. Lancet 2016; 388: 2153-63 